\title{
Analisis Tingkat Keusangan dan dan Paro Hidup Literatur Monograf yang Disitir pada Skripsi Mahasiswa Program Studi Ilmu Perpustakaan Fakultas Adab dan Humaniora UIN Sulthan Thaha Saifuddin Jambi Tahun 2017-2020
}

\author{
1Martha Galuh Ari Pangastuti, Wenny Dastina \\ ${ }^{1}$ Fakultas Adab, UIN Sulthan Thaha Saifuddin Jambi \\ ${ }^{1}$ Fakultas Syariah, UIN Sulthan Thaha Saifuddin Jambi \\ Jalan Jambi - Muaro Bulian Km.16, Muaro Jambi, 36363 \\ e-mail: marthagaluh00@gmail.com
}

\begin{abstract}
Introduction This study aims to determine the level of obsolescence and half-life of monograph literature used in thesis writing for students of the Library Science Department, Faculty of Adab and Humanities, UIN Sulthan Thaha Saifuddin Jambi. This is on top of the importance of using new literature in every scientific writing to show progress or developments in the field of science.

Research methods. The research uses quantitative methods with a bibliometric approach.

Data analysis. data analysis using bibliometric analysis formula in finding the level of obsolescence and half-life of documents.

Results and Discussion. The results show that the highest level of literary obsolescence is found in the thesis in 2019 with a percentage of 55.87\% of the 571 books cited, which are 319 books, and the lowest level of obsolescence is found in the thesis in 2017 with a percentage of $46.22 \%$ of the 357 cited books, namely a total of 165 books. While overall from 2017-2020 the average obsolescence rate obtained was $50.89 \%$. For the level of up-to-date literature is $49.31 \%$ based on the average age of the half-life obtained, which is 10.39 years.

Conclusions and suggestions. Looking at the percentage of monograph literature used in student thesis writing, there are $49.31 \%$ new literature and $50.89 \%$ obsolete literature. So it can be said that more than half of the monograph literature used in student research is not up-to-date. Libraries located in higher education institutions at the level or level that have the skills to meet user needs, especially in making thesis by providing the latest literature can present up-to-date and useful information in the development of science, especially in the field of Library Science.
\end{abstract}

Key word: Bibliometric Analysis, obsolescence of monograph literature, half-life of monograph literature 


\begin{abstract}
ABSTRAK
Pendahuluan. Penelitian ini bertujuan untuk mengetahui tingkat keusangan dan paro hidup literatur monograf yang digunakan pada penulisan skripsi mahasiswa Program Studi Ilmu Perpustakaan Fakultas Adab dan Humaniora UIN Sulthan Thaha Saifuddin Jambi. Hal ini di dasari atas pentingnya penggunaan literatur baru dalam setiap penulisan karya ilmiah untuk menunjukkan kemajuan atau perkembangan pada bidang ilmu tersebut.

Metode penelitian. Penelitian menggunakan metode kuantitatif dengan pendekatan bibliometerika.

Data analisis. analisis data menggunakan rumus analisis bibliometrik dalam mencari tingkat keusangan dan paro hidup dokumen.

Hasil dan Pembahasan. Hasil penelitian menunjukkan bahwa tingkat keusangan literatur tertinggi terdapat pada skripsi tahun 2019 dengan persentase 55,87\% dari 571 buku yang disitir yaitu sebanyak 319 buku, dan tingkat keusangan terendah terdapat pada skripsi tahun 2017 dengan persentase 46,22\% dari 357 buku yang disitir yaitu sebanyak 165 buku. Sedangkan secara keseluruhan dari tahun 20172020 tingkat keusangan rata-rata yang diperoleh sebanyak 50,89\%. Untuk tingkat kemutakhiran literatur adalah 49,31\% berdasarkan usia rata-rata paro hidup yang diperoleh yaitu 10,39 Tahun.

Kesimpulan dan saran. Melihat data presentase literatur monograf yang digunakan dalam penulisan skripsi mahasiswa yakni, terdapat 49,31\% literatur baru dan 50,89\% literatur usang. Maka dapat disimpulkan bahwa lebih dari setengah literatur monograf yang digunakan dalam penelitian skripsi mahasiswa tidak mutakhir. Perpustakaan yang berada di linkungan Perguruan Tinggi baik di tingkat universitas ataupun tingat fakultas hendaknya memenuhi kebutuhan pengguna terutama mahasiswa dalam penulisan skripsi dengan cara menyediakan literature terbaru sehingga bisa menyajikan informasi terkini dan berguna di dalam perkembangan ilmu pengetahuan khususnya di bidang Ilmu Perpustakaan.
\end{abstract}

Kata Kunci: Analisis bibliometrik, literature usang, paro hidup literature, Ilmu Perpustakaan dan Informasi

\title{
A. PENDAHULUAN
}

Dalam Pedoman Penyelenggaraan Perpustakaan Perguruan Tinggi Tahun 2015, dijelaskan bahwa perpustakaan perguruan tinggi merupakan unit pelaksana teknis yang bersama dengan unit lain melaksanakan tri dharma perguruan tinggi, dengan cara menghimpun, memilih, mengolah, merawat dan melayani sumber informasi kepada lembaga induk khususnya, serta masyarakat akademis pada umumnya (Darwanto, dkk, 2015: 2).

Menurut Peraturan Pemerintah Republik Indonesia Nomor 24 Tahun 2014 tentang Pelaksanaan Undang-Undang Nomor 43 Tahun 2007 tentang Perpustakaan, pasal 1 angka 10 mengamanatkan bahwa, yang dimaksud dengan perpustakaan perguruan tinggi adalah perpustakaan yang merupakan bagian integral dari kegiatan pendidikan, penelitian dan pengabdian kepada masyarakat dan berfungsi sebagai pusat sumber belajar untuk mendukung tercapainya tujuan pendidikan yang berkedudukan di perguruan tinggi. Tujuan 
penyelenggaraan perpustakaan perguruan tinggi yaitu untuk menunjang pelaksanaan program perguruan tinggi, sesuai dengan tri dharma perguruan tinggi yaitu: pendidikan dan pengajaran, penelitian, serta pengabdian pada masyarakat dengan menyediakan bahan perpustakaan dan akses informasi bagi pemustaka, meningkatkan literasi informasi pemustaka dan mendayagunakan teknologi informasi dan komunikasi serta melestarikan bahan perpustakaan, baik isi maupun medianya (Darwantodkk, 2015: 5).

Koleksi perpustakaan merupakan salah satu faktor utama sebuah perpustakaan. Kualitas dan kesesuaian koleksi dengan kebutuhan pemustaka sangat dipengaruhi oleh faktor pengadaan dan evaluasi bahan pustaka. Salah satu kriteria penilaian layanan perpustakaan yang bagus dapat dilihat dari kualitas koleksinya. Koleksi yang dimaksud tentu saja mencakup berbagai format bahan dengan perkembangan dan kebutuhan alternatif para pemakai perpustakaan terhadap media rekam informasi. Koleksi bahan pustaka di perpustakaan harus berkembang sesuai dengan zaman dan kebutuhan informasi masyarakat. Koleksi dikatakan bermanfaat apabila sesuai dengan kebutuhan informasi dan digunakan oleh pemustakanya (Rafiuddin, 2018: 35). Salah satu upaya yang dilakukan pustakawan untuk tetap menjaga kualitas koleksi di perpustakaan adalah dengan melakukan kegiatan analisis koleksi bahan pustaka.

Perpustakaan dapat dikatakan bagus apabila perpustakaan tersebut dapat memenuhi kebutuhan penggunanya. Apalagi di perguruan tinggi mahasiswa banyak melakukan penelitian salah satunya untuk dijadikan syarat kelulusan yaitu skripsi. Untuk penulisan skripsi mahasiswa membutuhkan banyak sekali sumber informasi baik dari buku wajib mata kuliah jurusan ataupun buku bacaan umum. Jadi, sudah seharusnya jika perpustakaan memiliki koleksi yang sesuai dengan kebutuhan pengguna.

Salah satu koleksi yang ada di perpustakaan adalah koleksi monograf. Koleksi monograf merupakan koleksi yang banyak dimiliki oleh perpustakaan Fakultas Adab dan Humaniora dibandingkan koleksi yang lain. Koleksi buku atau monograf yang dikoleksi oleh perpustakaan hendaknya bisa mendukung kegiatan penelitian yang dilakukan mahasiswanya. Perpustakaan hendaknya menyediakan buku-buku yang disitir oleh peneliti dalam penulisan ilmiah. Dengan adanya koleksi monograf dapat membantu mahasiswa dalam menyelesaikan tugas akhir. 
Buku atau monograf adalah terbitan yang membicara kan satu kesatuan pokok bahasan atau lebih yang ditulis oleh satu orang pengarang atau lebih dapat berupa terbitan tunggal ataupun lebih (PNRI, 2018: 9). Koleksi yang tersedia di perpustakaan perguruan tinggi hendaknya mengikuti perkembangan ilmu pengetahuan.

Menurut Lane dan Sandison dalam Sulistyo Basuki, perkembangan ilmu pengetahuan yang begitu pesat saat ini menyebabkan semakin banyak terciptanya literatur dengan informasi yang baru sehingga membuat informasi yang lama menjadi usang. Keadaan seperti ini merupakan dampak dari perkembangan ilmu pengetahuan dan disebut dengan istilah keusangan literatur (obsolescence). Keusangan literatur adalah penurunan atas waktu dan kesahihan atau pemanfaatan informasi (Sulistyo - Basuki, 1988: 90). Kajian tentang keusangan merupakan tindakan yang dilakukan terhadap perubahan penggunaan dokumen dalam waktu tertentu. Dalam kondisi seperti itu, suatu literatur dapat diukur keusangannya.

Penurunan penggunaan suatu literatur dapat disebabkan oleh beberapa faktor yaitu: Informasinya masih sahih (valid) namun telah disitir oleh literatur yang lebih baru, informasinya masih shahih, namun terdapat pada bidang/subjek yang semakin tidak diminati, dan informasinya tidak lagi sahih (Kartika, 2015: 3).

Dari uraian tersebut, dapat diketahui bahwa penurunan kemutakhiran suatu dokumen dipengaruhi dari beberapa faktor. Faktor tersebut yang dapat memengaruhi keusangan literatur dan akan menyebabkan terjadinya penurunan penggunaan dokumen. Penurunan penggunaan dokumen tersebut dapat dipengaruhi oleh beberapa faktor seperti penggunaan yang jarang terhadap dokumen, juga usia dokumen yang relatif sudah tua.

Kajian mengenai keusangan literatur dapat menjadi salah satu indikator untuk mengetahui kemutakhiran literatur dan kecepatan pertumbuhan literatur dan menunjukkan pertumbuhan bidang ilmu. Dengan kata lain, mengkaji pertumbuhan literatur dengan mengetahui tingkat keusangan literatur maka kita dapat memperkirakan perkembangan literatur yang akan datang.

Keusangan literatur dapat diketahui dengan melakukan evaluasi usia paro hidup suatu dokumen. Usia paro hidup (half-life) adalah usia separo dari seluruh literatur suatu bidang ilmu yang digunakan secara terus menerus sejak diterbitkan pertama kali. Paro hidup menunjukkan kecepatan pertumbuhan literatur, semakin muda usia paro hidup dokumen suatu bidang ilmu maka semakin cepat pertumbuhan ilmu tersebut (Sulistyo Basuki, 2004: 78) 
Sebagai contoh, paro hidup ilmu perpustakaan dan informasi yaitu 8 tahun. Apabila suatu literatur penelitian mengenai ilmu perpustakaan dan informasi menggunakan rujukan berusia lebih dari 8 tahun maka dapat dikatakan bahwa referensi yang digunakan sudah usang. Sebaliknya apabila rujukan yang digunakan berusia kurang atau sama dengan 8 tahun maka dapat dikatakan referensi tersebut masih baru atau mutakhir.

Maka berawal dari penjelasan diatas peneliti tertarik untuk mengkaji mengenai tingkat keusangan literatur monograf pada bidang ilmu perpustakaan, karena bidang ilmu perpustakaan merupakan bidang yang sangat erat dengan perkembangan kemajuan teknologi informasi.

Usia paro hidup pada bidang Ilmu Perpustakaan menjadi hal menarik diteliti bagi penulis untuk melihat bagaimana usia paro hidup dari bidang Ilmu Perpustakaan, untuk mengetahui berapa persen koleksi monograf yang disitir dalam pembuatan skripsi oleh mahasiswa Program Studi Ilmu Perpustakaan yang sudah usang dan koleksi monograf yang masih baru.

Dari uraian diatas maka peneliti tertarik untuk mengkaji lebih jauh mengenai Analisis Tingkat Keusangan dan dan Paro Hidup Literatur Monograf yang Disitir pada Skripsi Mahasiswa Program Studi Ilmu Perpustakaan Fakultas Adab dan Humaniora UIN Sulthan Thaha Saifuddin Jambi Tahun 2017-2020

\section{B. TINJAUAN PUSTAKA}

\section{Keusangan Literatur}

Istilah keusangan literatur pertama kali dikemukakan Line dan Sandison sebagai berkurangnya validitas dari kegunaan informasi seiring perkembangan zaman. Hal ini dikemukakan dalam berbagai subjek tergantung pada faktor alam, karakter subjek dan lain-lain (Sari \& Hendrawan, 2019: 127)

Menurut Hartinah dalam Elva Rahmah, keusangan literatur adalah penurunan dalam menggunakan suatu literatur atau kelompok literatur (pada suatu topik tertentu) pada suatu periode waktu karena literatur-literatur tersebut menjadi lebih tua. Kemudian menurut Hasugian dalam Elva Rahmah, keusangan informasi berarti bahwa informasi yang ada dalam sebuah dokumen semakin jarang digunakan, dengan kata lain penggunaan informasinya semakin menurun dan akhirnya pada suatu saat tidak digunakan lagi 
(Rahmah, 2011:123). Selanjutnya dalam Rahmah (2011: 125) terdapat dua tipe dasar keusangan (obsolescence) literatur yaitu obsolescence synchronous (mengukur keusangan dengan memeriksa tahun terbitan referensi literatur) dan obsolescence diachronous (mengukur keusangan dari sitiran yang diterima literatur tersebut).

\section{Paro Hidup Dokumen}

Usia paro hidup literatur yang diacu dengan melihat proporsi terbitan 10 tahun terakhir (kecuali bidang-bidang tertentu yang tidak banyak pembaharuan seperti hukum, taksonomi, arkeologi, dan matematika) merupakan tolak ukur mutu jurnal ilmiah yang penting. Karya klasik yang relevan dapat diacu sebagai sumber masalah tetapi tidak untuk pembandingan pembahasan atau tidak untuk membuktikan orisinalitas. Pengacuan pada tulisan sendiri (self-citation) yang terlalu banyak dapat mengurangi nilai jurnal ilmiah. (Direktorat Jenderal Penguatan Riset dan Pengembangan, 2018)

Maulidina (2012) menambahkan, bukan berarti penggunaan literatur sudah tua atau yang lama tidak dapat dijadikan sebagai bahan referensi untuk penelitian yang baru. Walaupun literatur tersebut tergolong lama atau sudah tua dalam hal usia paro hidup, apabila literatur tersebut memiliki informasi yang benar-benar relevan dengan topik yang dicari oleh pengguna informasi maka literatur tersebut dapat dijadikan sebagai bahan rujukan atau referensi untuk penelitian yang baru.

\section{Literatur Monograf}

Buku atau monograf adalah terbitan yang membicara kan satu kesatuan pokok bahasan atau lebih yang ditulis oleh satu orang pengarang atau lebih dapat berupa terbitan tunggal ataupun lebih (PNRI, 2018). Adapun ciri-ciri dari Monograf (Buku) diantaranya adalah dari segi isi, membahas membahas satu permasalahan pokok, kalaupun terdiri dari beberapa makalah (misalnya dalam prosiding seminar) maka semua makalah yang berhubungan dengan tema pokok dari seminar tersebut. Beberapa terbitan ada yang berjilid; Mempunyai halaman judul; Terdapat daftar isi; Teks yang dibagi dalam bab-bab; Terdapat lembar pendahuluan dan / atau kata pengantar; Terbit dalam satu jilid atau beberapa volume dengan bentuk jilid sama; dan umumnya memiliki ISBN (International Standard Book Number). 


\section{Karya Ilmiah}

Brotowidjoyo mengemukakan karya ilmiah adalah karangan ilmu pengetahuan yang menyajikan fakta umum dan ditulis secara metodologi penulisan yang baik dan benar, dan dapat dibuktikan benar tidaknya. Lebih lanjut beliau mengemukakan bahwa karya ilmiah harus ditulis dengan konkret, gaya bahasanya formal, dan kata-katanya teknis. (Brotowidjoyo, Pratomo \& Widodo, 2018: 2-3)

Karya ilmiah adalah tulisan yang didasari hasil pengamatan, peninjauan atau penelitian dalam bidang tertentu, kemudian disusun menurut metode tertentu dengan sistematika penulisan tertentu dan isinya dapat dipertanggung jawabkan keilmiahannya. Jenis-jenis karya ilmiah terdiri dari artikel, makalah, paper, skripsi, tesis, disertasi, jurnal. Skripsi adalah karya tulis ilmiah mahasiswa untuk menyelesaikan jenjang studiS1 (Sarjana). Skripsi memuat karya sistematis yang mengutarakanpendapat penulis berlandaskan pendapatorang lain.Pendapat yang diajukan harus didukung oleh data dan fakta empiris-objektif, baik berdasarkan penelitian langsung (observasi lapangan, atau percobaan dilaboratorium), juga diperlukan sumbangan material berupa temuan baru dalam bidangtata kerja, suatuhukum dan daliltertentu mengenaisalah satu bidang atau lebih spesialisasinya (Pratomo \& Widodo, 2018: 8-11).

\section{METODE PENELITIAN}

Jenis penelitian yang digunakan adalah penelitian kuantitatif dengan pendekatan bibliometrika. Lokasi penelitian di Program Studi Ilmu Perpustakaan Fakultas Adab dan Humaniora UIN Sulthan Thaha Saifuddin Jambi. Populasi dalam penelitian ini adalah skripsi mahasiswa program studi ilmu perpustakaan tahun 2017-2020 yang tersedia di Perpustakaan Fakultas Adab dan Humaniora Universitas Islam Negeri Sulthan Thaha Saifuddin Jambi. Teknik pengambilan sampel penelitian menggunakan total sampling sebanyak 236 skripsi. Metode pengumpulan data dilakukan denagn cara dokumentasi dan observasi.

Paro hidup dan keusangan literatur dihitung dengan mencari nilai median dari seluruh literatur yang disitir setelah terlebih dahulu dikelompokkan berdasarkan tahun penulisan skripsi. Berikut adalah rumus median yang digunakan (Selawati, Rohanda \& Yanto, 2020: 45) 


$$
M e=\mathrm{b}+\mathrm{p}\left(\frac{\frac{1}{2} n-F}{f}\right)
$$

Me $\quad=$ Median

b = Batas bawah kelas median (batas bawah -0,5). Hal ini dimaksudkan agar menjamin bahwa tidak ada data yang jatuh tepat di tepi kelas. Tepi kelas adalah setengah dari jumlah batas atas dan batas bawah dua kelas interval yang berurutan.

$\mathrm{p} \quad=$ Panjang kelas

$\mathrm{n} \quad$ = banyaknya data

$\mathrm{F} \quad=$ jumlah frekuensi kelas-kelas sebelum kelas median

f $\quad=$ frekuensi kelas median

Sebelum menentukan paro hidup maka dilakukan langkah-langkah sebagai berikut:

1) Menentukan banyaknya kelas $(\mathrm{K})$

$\boldsymbol{B} \boldsymbol{K}=\mathbf{1}+\mathbf{3}$, (n adalah banyaknya jumlah sitiran dalam jurnal)

2) Menentukan range atau selisih dengan cara mengurangi tahun terbit tertinggi dengan tahun terbit terendah.

\section{$R=X n-X I$}

3) Menentukan panjang kelas atau interval $P=$ RangeBanyak kelas

4) Membuat tabel distribusi frekuensi kumulatif

Keterangan:

$\begin{array}{ll}\mathrm{BK} & =\text { banyaknya kelas tahun terbit sitiran } \\ \mathrm{R} & \text { selisih tahun terbit sitiran tertinggi dengan tahun terbit sitiran } \\ & \text { terendah (range) } \\ \mathrm{P} & =\text { panjang kelas (interval) } \\ \mathrm{Xn} & =\text { tahun terbit tertinggi } \\ \mathrm{X} 1 & =\text { tahun terbit terendah }\end{array}$


Setelah usia paro hidup pada setiap tahun di peroleh, lalu dicari nilai rata-rata usia paro hidup keseluruhan tahun terbitan skripsi. Nilai paro hidup diperoleh melalui penjumlahan seluruh usia paro hidup skripsi dibagi dengan jumlah tahun yakni selama 4 (empat) tahun. Selanjutnya menganalisis seberapa besar sitiran valid dan sitiran usang pertahun terbitnya berdasarkan tabel distribusi frekuensinya. Berdasarkan nilai median yang telah diperoleh dapat dilihat berapa persen literatur yang baru dan usang dengan menggunakan teknik perhitungan sebagai berikut:

$$
P=\frac{f}{n} \times 100 \%
$$

Keterangan:

$\mathrm{P}=$ angka presentasi untuk semua kategori (baru dan usang)

$\mathrm{f}=$ frekuensi literatur berdasarkan tale distribusi

$\mathrm{n}=$ jumlah sitir

\section{HASIL DAN PEMBAHASAN}

Penelitian ini dengan membahas paro hidu dan tingkat keusangan literatur dengan menggunakan analisis sitiran terhadap literatur monograf berupa buku yang dipakai dalam menulis skripsi yang dibuat oleh mahasiswa program studi Ilmu Perpustakaan Fakultas Adab dan Humaniora Universitas Islam Negeri Sulthan Thaha Saifuddin Jambi dari tahun 20172020 yang tersedia di perpustakaan Fakultas Adab dan Humaniora.

\section{Tingkat Keusangan Literatur Monograf}

Tabel 1. Tingkat Keusangan Literatur Skripsi mahasiswa program studi Ilmu Perpustakaan Fakultas Adab dan Humaniora Universitas Islam Negeri Sulthan Thaha Saifuddin Jambi dari tahun 2017-2020

\begin{tabular}{|c|c|c|c|c|c|c|}
\hline Tahun & Median & Sitiran & Baru & $\%$ & Usang & $\%$ \\
\hline 2017 & 2006,85 & 357 & 192 & $53,78 \%$ & 165 & $46,22 \%$ \\
\hline 2018 & 2008,85 & 392 & 195 & $49,75 \%$ & 197 & $50,25 \%$ \\
\hline 2019 & 2008,39 & 571 & 252 & $44,13 \%$ & 319 & $55,87 \%$ \\
\hline 2020 & 2009,97 & 363 & 180 & $49,59 \%$ & 189 & $51,23 \%$ \\
\hline & alah & 1.683 & 819 & $197,25 \%$ & 870 & $203,57 \%$ \\
\hline \multicolumn{3}{|c|}{ Rata-rata Presentase } & & $49,31 \%$ & & $50,89 \%$ \\
\hline
\end{tabular}


Berdasarkan tabel di atas maka dapat diketahui bahwa dari 1.683 sitiran yang digunakan dalam penulisan skripsi mahasiswa Program Studi Ilmu Perpustakaan Fakultas Adab \& Humaniora UIN Sulthan Thaha Saifuddin Jambi dari tahun 2017 sampai 2020 yaitu sebanyak 819 sitiran atau 49,31\% dianggap sitiran baru dan sisanya yaitu sebanyak 870 sitiran atau 50,89\% adalah sitiran yang usang.

Keusangan literatur merupakan keadaan dimana menurunnya suatu literatur sebagai sumber informasi. Hal ini disebabkan oleh nilai dari literatur tersebut sebagai bahan informasi telah berkurang atau bahkan hilang, atau dikarenakan para pengguna lebih suka menggunakan literatur-literatur baru. Oleh karena itu, konsep keusangan merupakan konsep yang relatif, maka dari itu keusangan literatur pada setiap bidang ilmu akan terus berubah sesuai dengan perkembangan ilmu tersebut dan penggunaan literatur. Keusangan literatur dalam penelitian ini dihitung berdasarkan seberapa banyak literatur yang digunakan yang usianya dibawah usia paro hidup atau nilai median yang didapat.

Tingkat keusangan paling tinggi terjadi pada skripsi yang ditulis pada tahun 2019 dengan jumlah sitiran usang sebesar $55,87 \%$ yang artinya si atas setengah literatur yang digunakan merupakan sitiran yang usianya lebih dari paro hidupnya. Sedangkan keusangan yang paling rendah terdapat pada penulisan skripsi pada tahun 2017 yaitu memiliki keusangan 46,22\% yang artinya terdapat lebih dari setengah literatur yang digunakan 53,78\% merupakan literatur yang mutakhir atau referensi baru.

\section{Paro Hidup Dokumen}

Tabel 2. Paro Hidup Skripsi mahasiswa program studi Ilmu Perpustakaan Fakultas Adab dan Humaniora Universitas Islam Negeri Sulthan Thaha Saifuddin Jambi dari tahun 2017-2020

\begin{tabular}{|c|c|c|}
\hline Tahun & Sitiran & Paro Hidup \\
\hline 2017 & 357 & 10,15 tahun \\
\hline 2018 & 392 & 10,2 tahun \\
\hline 2019 & 571 & 10,61 tahun \\
\hline 2020 & 363 & 10,63 tahun \\
\hline \multicolumn{3}{|c|}{1.683} \\
\hline $\begin{array}{l}\text { Paro hidup } \\
\text { mahasiswa } \\
\text { Perpustaka }\end{array}$ & 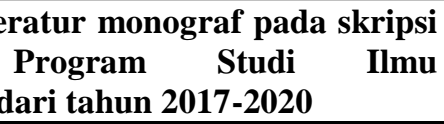 & 10,39 tahun \\
\hline
\end{tabular}


Dari hasil perhitungan paro hidup sitiran pada penulisan skripsi program studi Ilmu Perpustakaan per tahun terbitan,, maka diperoleh paro hidup dengan nilai rata-rata sebesar 10,39 tahun. Hal ini berarti bahwa setengah dari literatur yang digunakan dalam penulisan skripsi mahasiswa Program Studi Ilmu Perpustakaan berusia sekitar 10,39 tahun. Sehingga menunjukkan bahwa apabila sitiran yang digunakan dibawah 10,39 tahun maka menunjukkan bahwa informasi yang ada pada penulisan skripsi mahasiswa Program Studi Ilmu Perpustakaan tersebut adalah mutakhir. Sebaliknya, apabila sitiran yang yang digunakan di atas 10,39 tahun maka literatur tersebut masuk kategori usang.

Namun apabila merujuk pada Pedoman Akreditasi Jurnal Ilmiah (2018) dari KEMRISTEKDIKTI yang menyatakan bahwa Usia paro hidup literatur yang diacu dengan melihat proporsi terbitan 10 tahun terakhir (kecuali bidang-bidang tertentu yang tidak banyak pembaharuan seperti hukum, taksonomi, arkeologi, dan matematika) merupakan tolak ukur mutu jurnal ilmiah yang penting. Maka penulisan skripsi pada program studi Ilmu Perpustakaan yang memiliki paro hidup sebesar 10,39 tahun ini termasuk pada literatur yang usang. Pada penulisan skripsi mahasiswa program Studi Ilmu Perpustakaan banyak karya klasik yang relevan dapat sebagai acuan. Walaupun literatur tersebut tergolong lama atau sudah tua dalam hal usia paro hidup, apabila literatur tersebut memiliki informasi yang benar-benar relevan dengan topik yang dicari oleh pengguna informasi maka literatur tersebut dapat dijadikan sebagai bahan rujukan atau referensi untuk penelitian yang baru (Maulidina, 2012).

Berdasarkan data di atas maka dapat diketahui bahwa dari 1.683 sitiran yang digunakan dalam skripsi mahasiswa program Studi Ilmu Perpustakaan tahun 2017 hingga 2020 yaitu sebanyak 819 sitiran atau 49,31\% dianggap sitiran baru dan sisanya yaitu sebanyak 870 sitiran atau 50, 89\% adalah sitiran yang usang. Keusangan literatur merupakan keadaan dimana menurunnya suatu literatur sebagai sumber informasi. Hal ini disebabkan oleh nilai dari literatur tersebut sebagai bahan informasi telah berkurang atau bahkan hilang, atau dikarenakan para pengguna lebih suka menggunakan literatur-literatur baru. Oleh karena itu, konsep keusangan merupakan konsep yang relatif, maka dari itu keusangan literatur pada setiap bidang ilmu akan terus berubah sesuai dengan perkembangan ilmu tersebut dan penggunaan literatur. Keusangan literatur dalam 
penelitian ini dihitung berdasarkan seberapa banyak literatur yang digunakan yang usianya dibawah usia paro hidup atau nilai median yang didapat.

Tabel 3. Rekapitulasi keusangan dan paro hidup literatur

\begin{tabular}{|c|c|c|c|c|c|c|}
\hline No. & $\begin{array}{l}\text { Tahun } \\
\text { Skripsi }\end{array}$ & $\begin{array}{c}\text { Jumlah } \\
\text { Buku } \\
\text { Usang }\end{array}$ & $\begin{array}{c}\text { Jumlah } \\
\text { Buku } \\
\text { Baru }\end{array}$ & $\begin{array}{c}\text { Persentase } \\
\text { Usang }\end{array}$ & $\begin{array}{c}\text { Persentase } \\
\text { Baru }\end{array}$ & Paro Hidup \\
\hline 1 & 2017 & 165 & 192 & $46,22 \%$ & $53,78 \%$ & 10,15 tahun \\
\hline 2 & 2018 & 197 & 195 & $50,25 \%$ & $49,75 \%$ & 10,2 tahun \\
\hline 3 & 2019 & 319 & 252 & $55,87 \%$ & $44,13 \%$ & 10,61 tahun \\
\hline 4 & 2020 & 189 & 180 & $51,23 \%$ & $49,59 \%$ & 10,63 tahun \\
\hline \multicolumn{2}{|c|}{ JUMLAH } & 819 & 870 & - & - & - \\
\hline \multicolumn{2}{|c|}{ RATA-RATA } & - & - & $50,89 \%$ & $49,31 \%$ & $10,39 \%$ tahun \\
\hline
\end{tabular}

Dari tabel tersebut, maka dapat diketahui untuk tingkat keusangan literatur tertinggi terdapat pada skripsi tahun 2019 dengan persentase $55,87 \%$ dari 571 buku yang disitir yaitu sebanyak 319 buku, dan tingkat keusangan terendah terdapat pada skripsi tahun 2017 dengan persentase 46,22\% dari 357 buku yang disitir yaitu sebanyak 165 buku. Sedangkan secara keseluruhan dari tahun 2017-2020 tingkat keusangan rata-rata yang diperoleh sebanyak 50,89\%. Untuk tingkat kemutakhiran literatur adalah 49,31\% berdasarkan usia rata-rata paro hidup yang diperoleh yaitu 10,39 Tahun.

\section{E. KESIMPULAN}

Berdasarkan analisis hasil penelitian yang telah dilakukan, maka tingkat keusangan literatur monograf yang terdapat pada skripsi Mahasiswa Program Studi Ilmu Perpustakaan Universitas Islam Negeri Sulthan Thaha Saifuddin Jambi dapat disimpulkan sebagai berikut:

1. Usia paro hidup literatur buku yang disitir pada skripsi tahun 2017 adalah 10,15 tahun dengan frekuensi sitiran literatur buku monograf untuk tingkat keusangan tinggi yaitu 46,22\% dan untuk sitiran literatur monograf yang masih baru yaitu 53,78\%.

2. Usia paro hidup literatur buku yang disitir pada skripsi tahun 2018 adalah 10,2 tahun frekuensi sitiran literatur buku monograf untuk tingkat keusangan tinggi yaitu 50,25\% dan untuk sitiran literatur monograf yang masih baru yaitu $49,75 \%$. 
3. Usia paro hidup literatur buku yang disitir pada skripsi tahun 2019 adalah 10,61 tahun dengan frekuensi sitiran literatur buku monograf untuk tingkat keusangan tinggi yaitu $44,13 \%$ dan untuk sitiran literatur monograf yang masih baru yaitu 55,87\%.

4. Usia paro hidup literatur buku yang disitir pada skripsi tahun 2020 adalah 10,63 tahun dengan frekuensi sitiran literatur buku monograf untuk tingkat keusangan tinggi yaitu 51,89\% dan untuk sitiran literatur monograf yang masih baru yaitu 49,59\%.

Untuk tingkat keusangan literatur tertinggi terdapat pada skripsi tahun 2019 dengan persentase 55,87\% dari 571 buku yang disitir yaitu sebanyak 319 buku, dan tingkat keusangan terendah terdapat pada skripsi tahun 2017dengan persentase 46,22\% dari 357 buku yang disitir yaitu sebanyak 165 buku. Sedangkan tingkat keusangan rata-rata yang diperoleh sebanyak 50,89\%. Untuk tingkat kemutakhiran literatur adalah 49,31\%. berdasarkan usia ratarata paro hidup yang diperoleh yaitu 10 Tahun. Maka dari itu, literatur dengan usia lebih dari 10 tahun dianggap sudah usang atau tidak mutakhir lagi, sedangkan literatur dengan usia kurang dari 10 tahun dianggap masih valid sehingga layak digunakan sebagai literatur dalam penulisan skripsi mahasiswa program studi Ilmu Perpustakaan Fakultas Adab dan Humaniora Universitas Islam Negeri Sulthan Thaha Saifuddin Jambi.

\section{DAFTAR PUSTAKA}

Agus Pratomo \& Andi Widodo. (2018). Penulisan Karya Tulis Ilmiah. Sidoarjo:Nizamia Learning Center

Badan Peneltian dan Pengembangan Pertanian, (nd). "Mengenal Bahan Pustaka dan Cara Mengelolanya”, (Seri Pengembangan Perpustakaan Pertanian No. 1)

Darwanto dkk. (2015). “Pedoman Penyelenggaraan Perpustakaan Perguruan Tinggi”. Jakarta : Perpustakaan Nasional RI.

Direktorat Jenderal Penguatan Riset dan Pengembangan. (2018). Pedoman Akreditasi Jurnal Ilmiah. Jakarta: Direktorat Jenderal Penguatan Riset dan Pengembangan Kementerian Riset, Teknologi, dan Pendidikan Tinggi

Direktorat Jenderal Penguatan Riset dan Pengembangan. (2018). Pedoman Akreditasi Jurnal Ilmiah. Jakarta: Direktorat Jenderal Penguatan Riset dan Pengembangan 
Dwi Eliana Sari, Muhammad Rosyihan Hendrawan. (2019). “Analisis Sitiran Skripsi Program Studi Ilmu Perpustakaan Fakultas Ilmu Administrasi Universitas Brawijaya tahun 20152017’. Jurnal berkala ilmu perpustakaan dan informasi, Vol.15, No. 2, Desember

Elva Rahmah. (2011). “Kajian Bibliometrika Menggunakan Analisis Sitiran terhadap Skripsi Program Studi Pendidikan Bahasa dan Sastra Indonesia FBS UNP Tahun 2005-2009”. Jurnal Bahasa dan Seni Vol 12 No. 2 Tahun.

Machsun Rafiuddin dkk/ ( 2018). "Evaluasi Koleksi Bahan Pustaka di Perpustakaan”. Jurnal Adabiya, Vol. 20, No. 2, Agustus.

Maulidina, Winda. (2012). “Analisis Paro Hidup Usia Dokumen Yang Disitir Artikel Pada Jurnal Annals of Library and Information Studies (ALIS). http://repository.usu.ac.id/handle/123456789/34566

PNRI. (2018). Kebijakan Pengembangan Perpustakaan Nasional. Jakarta: Perpustakaan Nasional Republik Indonesia

Putu Gede Krisna Yudi Kartika, "Usia Paro Hidup dan Keusangan Literatur Jurnal Skala Husada Volume 11, 12 Tahun 2014-2015”,

Sulistyo - Basuki. (1988). Pengantar Ilmu Informasi: Buku Pedoman. Jakarta: Universitas Indonesia. . (2004). Pengantar Dokumentasi . Bandung: Rekayasa Sains. 